\title{
„Oramedia“ or Traditional Media as Effective Communication Options for Rural Development in Africa
}

\author{
by Frank Ugboajah
}

\section{Introduction}

There is often controversy even among Africans interested in the subject, on the best way to define and what to include in "Oramedia" or traditional/folk media. Perhaps the way to illustrate symbolically what folk media are is to take the way the African villager often explains himself tell a story: A British Governor once sat on the stool of the King of Ashanti as a way of communicating his authority as the representative of Queen Victoria of England. But the significance of the stool in the mind of the people of Ashanti was reverence, as being not an appurtenance of the kingly office, but that of an embodiment of the nation's soul. They were insulted. They were provoked. They went home and prepared for war!

Folk media are grounded on indigenous culture produced and consumed by members of a group. They reinforce the values of the group. They are visible cultural features, often quite strictly conventional, by which social relationships and a world view are maintained and defined. They take on many forms and are rich in symbolisms. In the short story told above one can see that the ignorant British Governor was thinking about a throne, signifying power and authority, whereas the people were thinking about religion and the sacredness of a stool. What resulted was an incongruity of communication which manifested into hostilities. Folk media cannot therefore be separated from folk cultures in whose context they are significant. One can look at folk media as group media but it is better to regard them as interpersonal media speaking to the common man in his language, in his idiom, and dealing with problems of direct relevance to his situation.

Attempts have been made to delineate the characteristics of folk media. They have been described as being simple in form and generally available to all at no material cost. They are said to be in the public domain. They are anonymous in origin. There is little differentiation between their producers and their consumers and they communicate directly through any of the senses via traditional folk ways. "Oramedia" are made up of dialogue and verbal exchange, a benefit that is provided by almost constant presence of one or more surrounding listeners. They are functional and utilitarian by way of definition. Their most important purpose is to provide teaching and initiation, with the object of imparting traditional aesthetic, historical, technical, social, ethical and religious values. They provide a legal code of sort which rests on stories and proverbs generated through the spoken word. They also play other roles in the village society such as by mobilizing people's awareness of their own history, by magnifying past events and evoking deeds of illustrious ancetors. Thus they tend to unite a people and give them cohesion by way of ideas and emotion. An aspiring Africa researcher in this field, Desmond Wilson, complaining about the word "mass" has this to say!

Dr. phil. Frank Ugboajah ist Professor im „Department of Mass Communications“ der Universität von Lagos, Nigeria. 
„... To those who have come to equate the word mass with such concepts as 'mass audience" or 'the global villages, the application may seem a bit of a misnomer given the image and picture of the large population of people that are of ten involved in these 'mass' concepts. But we are talking about little communities, clans, villages ... numbering a few thousands in scattered settlements ... whose desires for information (are) adequately met through the information machinery that exists with them ... For our purpose, the mass medium shall be defined as that through which large numbers of people are reached through any of our traditional mass media, namely, 'eyei', 'nnukenin', 'obodom', 'ntakrok', 'nkwong', and others. Our definition subsumes the fact that the millions of people watching a World Cup final on television and at the arena itself constitute the same kind of mass audience as the few thousand people who hurry to the village square to listen to their elders on hearing the call of the 'obodom'. In their different way the two channels - television and 'obodom" - constitute media of mass communication, their importance is not solely determined by sheer size of one but by the objective and effects of both media. ${ }^{\alpha 1}$

\section{Contemporary Use of Folk Media in African Communities}

Traditional Media are consistently used to promote the sense of nation-hood in Africa despite the low or absent priority given to them in official circles. The diagram below illustrates a typical flow of influence in a Nigeria village.

One observes at once that the formal media become little used immediately, communication or information reaches the traditional authority usually represented by a king or a chief or a Council of Elders in other respects. Communication from that point takes a diffusion approach and is dominated by the informal media or oral media ("Oramedia"), otherwise the traditional media or oral media represented by a diffusion network of lower chiefs, age groups, the marketplace, market women organisations, traditional priests, stall heads, village teachers and the indomitable village crier or gongman.

In Nigeria, age groups - Ogboni, Egbe, Egungun, Oro, Agemo, Dagboulu - meet periodically to discuss village development affairs according to priorities set by the village authority. The age groups also teach the young villagers the norms of society. Names of age-group members usually relate to spectacular events at the time of their birth. For example, the cohort or age group "Obangbade" is named after the fact that they were born at the time of the installation of a chief.

The "Parakoyi" is the traditional government of a Yoruba village marketplace described as "a conglomeration of all the media modes common to the village", which includes the Ashipa (the gongman) the Oluwo, the Iya Oja or village mother, the Ifa and Osayin priests.

The Parakoyi has both a ritualistic and judicial function in the market government. It maintains law and order, offers sacrifices to the Oloja (the god of the market) and collects taxes for the local authority.

Marketplaces throughout Africa, in themselves, are veritable communication forums. In Accra, Ghana, the "Queen Mothers" celebrate the "Homowo" Festival annually. This is a market festival to give thanks to the market gods. Marketplaces are not just where people go to buy or sell but are diffusion forums for important social interactions. Vogues are copied from marketplace. They are places of censure. In some villages in the eastern part of Nigeria, a case of incest is punished by parading the offend- 
Flow of Influence in an African Society

(The Case of Yorubaland)

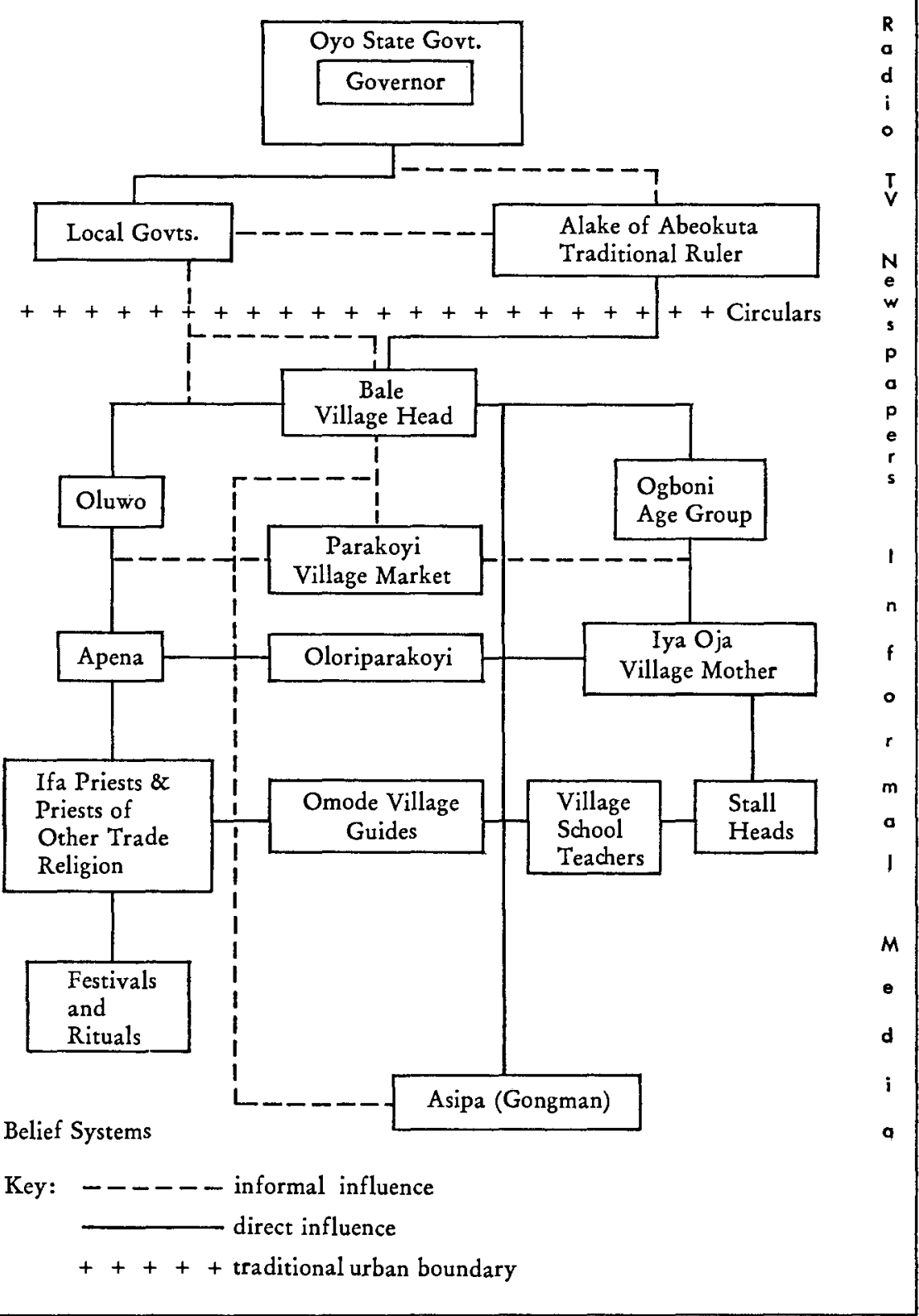


er adorned with a necklace of snail shells and live millipeds in the market place. An unmarried woman who gets pregnant while still living with her parents is censured with a song made up for her in the marketplace by her peers. Stealing farm products or livestock earns instant punishment by disgrace in the marketplace. It is no wonder that the Seminar on Motivation, Information and Communication for Development in Africa and Asian Countries held in Ibadan, Nigeria (July 1 - 9, 1974) drew attention to the fact that the marketplace "remains effective at all times because of the tremendous amount of interaction it generates". Marketplace news usually centre around personal information such as marriages, birth, deaths, broken homes, government and village council programmes. Communication in this forum goes on in both verbal and nonverbal forms. Unions in the marketplace serve as sub-forums for economic co-operation and social communication.

\section{Effectiveness Of Traditional Media And Belief System}

There is a popular proverb among the Yoruba of Nigeria: "Imale o pe kawa ma soro" which means "The fact that we are Muslims does not forbid us from worshipping the traditional gods or performing rituals". A man can be a Christian and might still perform traditional rituals. He might still consult the priest of the Ifa Oracle to tell him whether it is safe to go on a journey or not. He might still turn to Oshun the god of fertility or Obatala, the god of the creation or Yemaja, the god of the sea, when confronted with urgent personal problems. A whole village or clan in Africa could turn to the gods during the time of natural disasters such as famine, drought, epidemic and wars.

Africans, no matter the depth of their education or Christian and Islamic affiliation, have often turned to traditional belief and practice for consolation in times of crises. This was mainfested in Uganda in the case of the exile of the Kabaka of Uganda in 1953-1955 and during the bloody dictatorship of General Idi Amin. The same attitude was mainfested during the Biafra - Nigeria Civil War. Mau Mau oaths in the late 1950's starting as rituals culminated into nationalism to unite the people of Kenya against the colonial authority. For whatever their verbalisations, Africans have by no means abandoned their allegiances to traditional supernatural forces when they have accepted the deity of another people. Rather, the new deity is added to the totality of supernatural resources on which they call for aid. Credit should therefore be given to the newly-founded "Christian" churches in Africa, especially the Aladura Church of the Ord, for cashing in on the failure of the older churches by adapting and providing a transfusion of the African ontological dynamism, of the African enthusiasm, of the African feeling for substance in ritual and of the African recognition of the imminent and every day communal consequences of religious belief, practice and adaptation.

J.W. Fernandex has assailed the inappropriateness of the Bible to African peoples calling it "a diverse and ambitious mythological document ... which provides no information except of a very expressive or non-instrumental kind and develops no skill except in the endless subtleties of exegetical interpretation". Such a strong observation might not necessary be directed at the Bible per se but at the "hell fire" way in which it is presented. It is relieving that the 1974 Synod of African Bishops recognised the "inculturation to make the African Church authentically African ${ }^{\alpha}$. According to Action Resource of October 1980, the Bishops were amazed at the strategy of "the independent churches of Africa" especially the relative ease with which these churches draw people in big numbers to their fold while expanding rapidly. The 
Synod recognised that the media of communication of these independent churches were more often suitable and rooted in the African mentality and culture than the media the Catholics use in their churches and homes. In using traditional African media, the Bishops have recognised that "our people are able to develop authentic and creative art forms which are bound, to bear fruit in our liturgies and forms of worship, rooting our christian faith ever more firmly in African's soil ..." It should also be on record that the Roman Catholic Church and older churches in Africa have traditionally not overlooked the importance of indigenous structures such as agegroups mentioned above. These organisations have been of tremendous advantage in community actions to build village churches and mission schools. Even mission catechists, parish priests and mission teachers became a part and an extension of the community information network (as seen in the diagram above) and they have constituted themselves important opinion leaders and legitimizers on most topics and issues that affect the lives of villagers. What has been apparently lacking is the recognition of the impact of other more important belief systems, such as African traditional worships and folkways. The important thing to a villager or rural person is that the source where information comes from is reliable.

Belief systems could be cognitive or evaluative in their orientation, composing of symbols with either empirical or superempirical referents. In Ghana, the news of a birth is communicated to a husband by an assistant Ogyeafo ("traditional midwife") by tying a piece of white cloth round the wrist. A white cloth symbolises victory and proclaims that a baby has been delivered successfully. Also in Ghana, the Mantse or Chief does not speak directly to his people. He speaks through a linguist or sends his messages through the gongman using a set of talking drums. In Nigeria, among the Yoruba, the "edan" or the chief's staff is a symbol of authority for summoning an offender to the Chief's court. Anyone waking up in the morning to find the "edan" at his door must report to the Chief's Court first thing. The "Uhue" among the Igbo of Nigeria is used for announcing village festivities or to herald the arrival of the planting season. As a medium it is used late at night or early in the morning when people can be reached. Within the next minutes the air is filled with - heavy rhythms. But the strange observation is that no word follows. Meaning thus becomes symbolic and is shared by all. This contrasts with the ethnocentric and culturedamaging "Tarzan movies" where the "Uhue" sound would have been portrayed as "natives" getting ready to cannibalise their "captive" or something of the sort.

Belief systems constitute the basis of the villager's experience and are integral and functional part of his society. Thus rural villages contrary to some other observations, are functioning subsystems in accordance with the tenets of belief systems. Traditional media linked to belief systems have been found effective as tools in development programmes of governments. As entertainments they can attract and hold the interest of large numbers of people. As oral media in local languages they can involve the poorest groups and classes who are often left out of development activities because of illiteracy or lack of understanding of the English or French language. As dramatic representations of local problems, they can provide a codification of reality which can be used by participants in analysing their situation. And as collective expressions and communual activities they create the contexts for cooperative rather than individual thinking and action. They create a great possibility for peer learning.

China has been lauded as reconstructing a village society. The village then actively moulded the kind of school it felt it needed. Rural primary education in China is 
directly relevant to the social and economic goals of the commune and villagers take an active part in the operation of their learning system. In Java, the use of the folk puppetry opera (ludruk), comedy (neog) and the shadow puppet play (evajang golek golek) as the trusted media for conveying new ideas to people has been adopted by change agents. Singing poets (cantadores) in Brazil, cowhide characters (nang taloogn) in Thailand and dramatised poetry (ngonjera) in Tanzania are being used to the same end. "Panchatantra" has now become an effort to examine the fields of myth, legends, folklore in general by India's Space Applications Centre.

Experience in Botswana has shown that popular theatre can play an important role in social transformation programmes, expanding participation and self-confidence and providing a mirror for critical analysis and a stimulus for discussion and action. It is very important that we recognise that the answers villagers give to natural challenges are cultural. These cannot be replaced by superimposing equally cultural responses that we extend to them.

The "Seminar on Motivation, Information and Communication for Development in African and Asian Countries, "mentioned above (in which this author participated) has listed the following media structures as those that have potentials for development purposes in Afro-Asian countries:

1. Gongman/Town Crier - usually a member of the household of the local leader who is responsible for delivering messages from the traditional leader orally to elders and community leaders in the locality. He moves about on foot, usually within a radius of five miles.

2. State/Talking Drum - official drums bigger or larger in size than normal drums used as veritable channels of communication, such as call signals (most African radio stations have adopted this) inter-village communication, official messages from the chief or Council of Elders.

3. Hornman - a communicator who uses a horn for call signals and belongs to voluntary associations active in the neighbourhood. He is used in a special but limited way.

4. Visual Symbols and Colours - messages transmitted through this channel are mainly moral and artistic. The impact of this channel is great. A certain care should have to be exercised with regard to the use of colour which has different symbolic meaning or value in different cultures.

5. Minstrel - a communicator who operates through song of ten accompanied by local instruments. He seeks his audience in a homogenous group. The song has in general a bearing on particular situations.

6. Poets and Reciters - very popular and adaptable channel of communication. Through this channel are transmitted moral, social and educational messages. It is currently popular in radio transmissions.

7. Story Tellers - communicators who specilize in messages of educational, historical or entertainment values - usually loaded with morals.

8. Drama, including Dance, Mime and Puppetry - convey educational, moral and social messages. This is a convenient vehicle for the integration of a variety of traditional media and is capable of carrying this advantage to all types of modern media.

9. Traditional Leaders - for development messages, attention is particularly drawn to the following: local Chiefs and their substructures (see diagram above) group lead- 
ers, elders, religious leaders, native doctors, midwives, parents, teachers, the entire extended family system and clans.

10. Social Structures - the marketplace, forums such as the Chief's courts, assemblies of elders, religious institutions, voluntary ward groups and cooperatives. Note that special attention is drawn by the Seminar to the tremendous amount of interaction the market place generates.

\section{Conclusion: Need For Research}

In the area of technological transfers, as observers have pointed out, the error has been that of seeing reality as a totality. This error is repeated, as a case in point, in an attempt to train peasants by adopting an ingenous attitude to the problem of techniques. That is when it is not made obvious that techniques do not just happen. That polished "elaborated" techniques like the science of which they are a practical application, are socio-historically conditioned. Techniques can be applied for development by adopting the principle of "conscientization". Such techniques as socio-drama consists of theatrical presentations with elements and themes drawn from the community and using people from the community. The outcome is the obtaining of as much information as possible and the provision of interpretations of actual events. At the same time there is an attempt at carrying out basic activation exercise that leads to greater flexibility in the way the group projects itself without becoming too technical. Music, humour, songs and dialogue are used to stimulate the emotive and critical reactions of the spectators and these act as the catalyst in a cultural cycle.

Economic and political power and power over mass mediated communication in Africa are concentrated in a small elite and or colonial representatives. Invariably, lower-status groups mostly found in the eighty-five percent of the population which makes up the villages establish their own alternative communication so as to have an independent organisation and voice. That alternative communication is what this essay has been discussing.

The "Yaounde Declaration On Communication Policies in Africa" adopted by the Inter-governmental Conference on Communication Policies held in 1980, underscored the importance of this alternative communication. Section Three of that Declaration holds in part that "Africa represents a special human context, in which the living forms of traditional communication can be harmoniously linked up with the boldest conquests of modern communication. The systematic and apt use of local and national languages by the various media can help to prevent the gulf between the ordinary people and the elites form widening. Modern means of communication, by disseminating culture to a vast national and regional public, will enable each African people to gain deeper insight into their own personality and like-wise to discover that of other countries." Also the principles of a $\mathrm{New}$ World Information and Communication Order (NWICO) Section IV (i) (a), by UNESCO, includes "the removal of internal and external obstacles to free flow and wider and better balanced dissemination of information" as well as "plurality of sources and channels of information". It also underscores the capacity of developing countries to achieve improvement of their own situations by providing their own equipment, training their personnel, improving their infrastructures, and making their information and communication means suitable to their needs and aspirations. The development and utilisation of the traditional media for participation in Africa is a major way of responding to NWICO. 
Though the use of traditional media might be favoured because they are long-established, well accepted and credible, some researches are still doubtful that their potentials are far from being realised in our modern world. The challenge facing today's communication specialist in Africa is the need to understand clearly what results the folk media could achieve for mobilisation and for development. Unfortunately there are no well-organised data from those countries in which "Oramedia" have been employed in social development to strengthen a case for their wider utilization in the African region. Research calls therefore for the following tasks:

1. a comprehensive annotated world-wide bibliography on the use of traditional media;

2. an inventory of folk media systems and structures showing their origins and purposes, their mode and format, their technological adaptations and their constraints;

3. specific case studies of major folk media structures or processes;

4. studies which involve possible integration of folk media forms with modern mass media or group media; and

5. effectiveness studies which compare one folk media structure against another.

There is a need to systematically identify the symbols that exist in traditional media channels and how these symbols are manipulated for effectiveness in communication. These challenges of research are formidable. They are challenges which need commitment and foresight in those who are genuinely convinced of the potentials and relevance of the folk media for information, education, entertainment and development in Africa.

\section{Footnotes}

1 Desmond E. Wilson: From the Gong to Electronics: A Survey of Trado-Modern Mass Communication Techniques in the Cross River State of Nigeria M. A. Thesis, University of Ibadan (1981).

2 J. W. Fernandex: Independent African Christianity: Its study and its Future. In: "Journal of Asian and African Studies" 4: 2, 1969, pp. 132-147.

Raul Alberto: Popular Theatre and Development in Latin America "Educational Broadcasting International", London, Vol 12, No. 1, March, 1979.

Henry T. Ingle: Communication Media and Technology: A Look at Their Role in Non-Formal Education Programmes. In: "Information Bulletin" (No. 5), New York: The Information Center On Instructional Tednology, Educational Development Incorporated.

E. Jengo: Folk Media and Social Development in Tanzania. In: John Balcomb (ed.): Communications For Social Development in Africa, Nairobi: UNICEF (1976), pp. 44-46.

Ross Kid: Folk Theatre: One Way or Two-Way Communication?. In: "Educational Broadcasting International“ London, Vol. 12 No. 1, March 1979.

Lungenyi - Lumwe Maalu-Bungi: Invention in Oral Literature, In: "Cultures" Vol. VII, No. 2, 1980, pp. 101-117.

"Action Resource", No. 4, October 1980.

Marlene Scholz: Group Media and Community Building. In: "Gaba Original", No. 3 June 1979.

Frank Okwu Ugboajah: Developing Indigenous Communication in Nigeria. In. "Journal of Communication“, Vol. 29: 4 (1979), pp. 40-45.

Robert White: Communicacion Popular: Language of Liberation. In: “Media Development", 3/1980, Vol. XXVII, pp. 3-9. 


\section{ZUSAMMENFASSUNG}

Wie „Oramedia“ oder traditionelle oder Folkmedien definiert werden können, ist auch unter Afrikanern umstritten. Ein britischer Gouverneur setzte sich einst auf den Stuhl der Ashanti, um seine Autorität als Vertreter der Königin Viktoria von England darzutun. Aber für die Ashanti bedeutet dieser Stuhl Reverenz, er ist die Verkörperung der nationalen Seele und nicht der königlichen Macht. Sie waren beleidigt und begannen Vorbereitungen zum Krieg.

Traditionelle Kommunikation gründet in der einheimischen Kultur, wie sie von deren Mitgliedern gestaltet und gelebt wird. Sie verstärkt die Werte der Gruppe und ist sichtbar in kulturellen Gegebenheiten, die oft in Konventionen durch gesellschaftliche Bande und ein Weltbild erhalten und bestimmt werden. Diese Kommunikation hat viele Formen und ist reich an Symbolen. An dem Beispiel des Ashanti-Stuhls erkennt man die Unwissenheit des britischen Gouverneurs, der glaubte, dieser Stuhl verkörpere Macht und Autorität, während er für die Einheimischen heilig war und religiöse Bedeutung hatte. Das Resultat war eine inkongruente Kommunikation, die Krieg zur Folge hatte. „Folkmedia“ können deswegen nirht vom Volk und seiner Kultur, von der sie ihre Bedeutung erhalten, getrennt werden. Man kann sie ansehen als Gruppenmedien, aber es ist wohl besser, sie als interpersonale Kommunikation zu betrachten, die zum einfachen Mann in seiner Sprache, in seinem Idiom spricht und sich mit Fragen seines Lebens und Alltags beschäftigt.

Man hat versucht, die Charakteristika dieser Kommunikation zu beschreiben: sie sind einfach in ihrer Form, gewöhnlich für alle ohne Kosten zugänglich, sie sind öffentlicher Besitz und anonym in ihrem Ursprung. Es gibt wenig Unterschied zwischen ihren Produzenten und den Konsumenten, sie kommunizieren unmittelbar über die Sinne in traditioneller Art. „Oramedia" bestehen im Dialog und in verbalem Austausch, und meist ist unmittelbare Gegenwart der Zuhörer gegeben. Sie sind durch Definition funktional und Gebrauchswerte. Ihre Hauptaufgabe ist Lehren und Einführen in traditionelle Werte von Asthetik, Geschichte, Technik, Gesellschaft, Ethik und Religion einer Kultur.

Sie geben einen rechtlichen Rahmen, der vor allem in Geschichten und Sprichwörtern durch das gesprochene Wort lebendig erhalten wird. Für die dörfliche Bevölkerung müssen sie das geschichtliche Bewußtsein der Menschen lebendig erhalten. Sie verbinden die Menschen und geben ihnen durch Ideen und Gefühle einen entsprechenden Zusammenhalt. In einer solchen Situation ist das Wort Masse völlig fehl am Platze.

Traditionelle Kommunikation wird ständig gebraucht, um den Sinn für das nationale Bewußtsein in Afrika lebendig zu erhalten. Sobald im Verlauf der Information die formellen Medien aufhören, beginnt der große Bereich der traditionellen Kommunikation, bei der zunächst ein König, ein Häuptling oder ein Rat der Alteren im Mittelpunkt steht. Von dort geht die Linie weiter zu den unteren Häuptlingen, Altersgruppen, Marktplätzen, traditionellen Priestern, Lehrern usw. (vgl. Schema).

Marktplätze in Afrika sind in sich wirkliche Kommunikationsformen. Sie sind weniger ein Platz, wohin die Menschen zum Kaufen oder Verkaufen kommen, sondern viel mehr Umschlagsplätze für gesellschaftliches Geschehen. Mode entsteht auf dem Marktplatz, er ist Ort des Gerichts und des Urteils. Marktplatz-Nachrichten betreffen meist Personen, sie drehen sich um Heimat, Geburt, Tod, Familien, Regierung und Dorfgeschehnisse. Marktplatzkommunikation ist verbal, aber auch non-verbal. Versammlungen auf dem Marktplatz dienen als Foren für wirtschaftliche Kooperation und soziale Kommunikation.

\section{Effizienz traditioneller Medien}

Trotz aller neueren Bindungen haben die Afrikaner ihren Glauben und ihre traditionellen übernatürlichen Quellen und Kräfte nicht verloren. Sie können Moslems und Christen sein und trotzdem ihren religiösen Traditionen anhängen. Hier liegt ein Grund für die Effizienz und das starke Wachstum der sgn. unabhängigen afrikanischen Kirchen. Wo die alten Kirchen es verfehlt haben, den afrikanischen ontologischen Dynamismus aufzugreifen, finden diese neuen Bewegungen mit einer eigenen Verbindung von Christen- und Afrikanertum ihren Nährboden. 
Hier ist es bemerkenswert, daß die Synode der afrikanischen Bischöfe von 1974 anerkannte, daß die „Inkulturation die Afrikanische Kirche authentisch afrikanisch" machen müsse.

Sie anerkannte auch, daß die unabhängigen Kirchen deswegen so erfolgreich seien, weil ihre Kommunikation oft mehr der afrikanischen Mentalität und Gesellschaft entspricht. Dabei erscheint es für den einheimischen Menschen wichtig, daß die Quelle der Information vertrauenswürdig ist.

Glaubenssysteme bestimmen die Erfahrung des einheimischen Menschen; für ihn sind sie integraler und funktionaler Teil seiner Gesellschaft. Deswegen sind auch die Dörfer auf dem Land Gesellschaftssysteme, die entsprechend dem Glauben und der Oberzeugung funktionieren. Traditionelle Medien, die in diesen Glaubenssystemen gründen, sind deswegen wirkungsvolle Elemente etwa für Entwicklungsprogramme von Regierungen. Als Unterhaltung können sie große Menschenscharen anziehen und in Atem halten. Wie verbale Medien in der einheimischen Sprache können sie auch die ärmsten Gruppen einbeziehen, die sonst oft von Entwicklungsaktivitäten abgeschnitten sind. Als dramatische Darstellung können sie örtliche Probleme aufzeigen, die Realität beschreiben und analysieren, sie schaffen den Kontext mehr für allgemeine als individuelle Überzeugungen und Aktivitäten ... Hier kann z. B. das Volkstheater eine große Rolle spielen. Man muß die Antwort der einheimischen Menschen auf die Erfordernisse ihres Lebens ernst nehmen und kann sie nicht ersetzen, indem man ihnen andere kulturelle Antworten überstülpt.

Ein Seminar über Motivation, Information und Kommunikation für Entwidklung hat die folgenden Strukturen als bedeutungsvoll für die Entwicklung in Afro-asiatischen Ländern aufgelistet: den Trommler und Stadtausrufer, die sprechende Trommel, den Hornbläser, visuelle Symbole und Farben, Minnesänger, Dichter und Rezitatoren, Geschichtenerzähler, Drama einschließlich Tanz, Mimik und Puppenspiel, traditionelle Führer und einheimische Sozialstrukturen wie Marktplatz, Gerichte, Versammlungen der Alteren, Religiöse Institutionen usw.

\section{Notwendige Forschung}

Beim Transfer technischer Fähigkeiten hat man oft nicht genügend die ganze Wirklichkeit gesehen. Auch entwidkelte Technologien haben ihr sozio-geschichtliches Umfeld. Kommunikationstedhniken können zuerst gebraucht werden zur Bewußtseinsbildung. Sie müssen aber von der Kultur der betreffenden Gemeinschaft ausgehen.

So sollten sie zu größerer Flexibilität führen. Wirtschaftliche und politische Macht über die Massenmedien ist in Afrika bei einer kleinen Elitegruppe konzentriert. Die etwa 85\% der Dorfbewohner aber gestalten ihre eigene alternative Kommunikation mit unabhängiger Organisation und Stimme. Um diese alternative Kommunikation geht es hier. Ihre Bedeutung wurde auch in der Yaounde-Erklärung einer Unesco-Konferenz über Kommunikationspolitik in Afrika 1980 unterstrichen. Aufgabe des Kommunikationsspezialisten in Afrika heute ist es, klar zu sehen, welche Rolle die traditionellen Medien für die Entwidklung spielen können. Leider gibt es dazu bisher kaum gut belegte Daten aus jenen Ländern, in denen die „Orame-

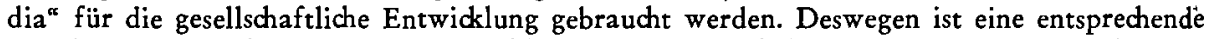
Forschung notwendig, die u. a. etwa Bibliographien entwickelt, eine Inventarisierung der entsprechenden Mediensysteme vornimmt, Fallstudien anfertigt, die Möglichkeiten der Integration von traditionellen und modernen Medien untersucht und die Effizienz verschiedener Systeme miteinander vergleicht.

\section{RESUME}

"Oramedia", folkmedia ou communications traditionnelles ont leur origine dans la culture indigène, ayant une grande variété et richesse de symboles. Elles ne peuvent pas être séparées d'un peuple et de sa culture. Elles sont simples dans la présentation et se laissent réaliser habituellement sans de grands frais. Elles sont de propriété publique avec très 
peu de différences entre leurs producteurs et leurs utilisateurs. "Oramedia" sont le dialogue, en général avec la présence immédiate des destinataires. Notamment les places de marché en Afrique sont des lieux d'échanges pour la communication traditionnelle. Les moyens de communication moderne ne servent qu'à approximativement $15 \%$ de la population africaine, le reste réalise sa propre communication alternative, sur laquelle une recherche scientifique étendue serait à faire d' urgence.

\section{RESUMEN}

"Oramedia", folkmedia o comunicaciones tradicionales, tienen su origen en la cultura indígena que tiene una gran variedad y riqueza de símbolos. Estas no pueden estar separadas de un pueblo y de su cultura. Son simples en su presentación y se pueden realizar generalmente sin grandes gastos. Son una propiedad pública con muy pocas diferencias entre sus productores y sus utilizadores. "Oramedia" son diálogo, en general con la presencia inmediata de los destinatarios. En especial los lugares de mercado en Africa son lugares de intercambio para este tipo de comunicación tradicional. Los medios modernos de comunicación sirven solamente a un $15 \%$ de la población Africana, el resto realiza su propia comunicación alternativa y sobre la cual una extensa investigación científica sería de urgente realización. 